\title{
Poliziano as a Philosopher, or The Craft OF THINKING BETWEEN FICTION AND HisTORY ${ }^{1}$
}

\author{
POLIZIANO COMO FILÓSOFO O SOBRE EL ARTE DE PENSAR \\ ENTRE FICCIÓN E HISTORLA
}

Guido Giglioni

\begin{abstract}
By concentrating on the work of Angelo Poliziano (1454-1494), this article explores the questions about whether and to what extent fictional accounts of reality may contribute to the crafting of rational arguments. I will present Poliziano's contribution to this debate as deeply embedded in a culture of verbal and visual mediation, as was characteristic of Renaissance philosophy. At a time and in a place (fifteenth-century Florence) where philosophy was open to forms of experimentation involving words and images, Poliziano was keen to defend the legacy of poetry, rhetoric and history within the tradition of philosophical inquiries, and more specifically, the role of fiction in shaping arguments and tools of analytical scrutiny. From an interpretative point of view, one of the guiding lines in my analysis will be the category known in contemporary philosophy as moral imagination, that is, the idea that the imagination has the ability to transcend the limitations of individual desire and create the conditions for a broader engagement with reality. It is a type of moral abstraction that allows ideals and values to become sufficiently general to be shared by communities (synchronically) and handed down by traditions (diachronically). It will be apparent how in Poliziano's account fiction, understood as the narrative element invigorating rational argument, expands the scope of imaginable possibilities while acknowledging the role played by the many constraints of history (res) and persuasion (fides).
\end{abstract}

KEYWORDS: fiction, history, res, moral imagination, Homer, Horace, Angelo Poliziano, Renaissance philosophy

\footnotetext{
1 A first version of this article was presented at the conference on "Pico and Poliziano in Late Medici Florence," held at UCL, London (15 May 2017), to honour the memory of Simona Mercuri (1976-2015), a most promising young scholar of Poliziano studies, who sadly died in the prime of her youth. I would like to thank here the organizers of the conference, Francesco Bausi and Anna Corrias, for their kind invitation and their comments during the discussion.
} 


\section{RESUMEN}

A través del análisis de las obras de Angelo Poliziano (1454-1494), este artículo se propone responder a dos preguntas: ¿Pueden las recreaciones ficcionales de lo real contribuir a la creación de argumentos racionales? Y, de ser así, ¿ hasta qué punto? A fin de contestarlas, presentaré la contribución de Poliziano en este debate enmarcándola en una cultura de mediación verbal y visual que es característica dentro de la filosofía del Renacimiento. En un lugar y en un tiempo (la Florencia del Quattrocento), donde la filosofía se abría a formas de experimentación que implicaban palabras e imágenes, Poliziano se interesaba en defender el legado de la poesía, la retórica y la historia dentro una tradición especulativa filosófica preocupada en la capacidad de la ficción para conformar argumentos y proporcionar herramientas que favorecieran el examen analítico. Desde un punto de vista interpretativo, una de las líneas rectoras de mi análisis coincide con aquello que la filosofía contemporánea denomina «imaginación moral», esto es, la idea de que la imaginación tiene capacidad de trascender las limitaciones del deseo individual y crear condiciones necesarias para una implicación más profunda con lo real. Se trata de una forma de abstracción moral que permite que valores e ideales devengan en suficientemente generales para ser compartidos por comunidades (sincrónicamente) y heredados a través de la tradición (diacrónicamente). Demostraré cómo, desde el punto de vista de Poliziano, la ficción — entendida aquí como el elemento narrativo que refuerza un argumento racional-, expande el alcance de lo imaginado posible al tiempo que reconoce las múltiples restricciones de la historia (res) y la persuasión (fides) en el dominio de la filosofía.

PALABRAS CLAVE: ficción, historia, res, imaginación moral, Homero, Horacio, Angelo Poliziano, filosofía del Renacimiento.

Cur igitur pudeat philosophari? Angelo Poliziano, Lamia

\section{INTRODUCTION: THE IMPACT OF FICTION ON PHILOSOPHY}

Do philosophers tell stories? Plato, famously, did. Are they supposed to tell stories? This question - the theoretical argument-is more complex and insidious than the first, the one dealing with the actual practice of philosophical inquiry and its history. As both Aristotle and Kant have taught us, the fact that philosophers tell stories does not mean that they have the right to do so; in fact, philosophers are the ones who are supposed to ask the question about the law or principle (quid iuris or the quidditas) behind a given practice, regardless of whether that practice 
comes to fruition or not (quid facti or the quodditas). ${ }^{2}$ In arguing for a legitimate use of fiction in philosophy and its limits, philosophers seem therefore to be in a quandary of their own making, in their ever recurring attempts to discipline themselves while often resorting to one of the most natural linguistic resourcesthe ability to tell stories - which is shared by individuals and communities at any given time in history. Philosophe, cura te ipsum, one may then jokingly say paraphrasing a well-known proverb-provided that fiction can in fact be seen as a malaise that affects philosophical arguments.

In addressing the question of the impact of fiction on early modern philosophy, we cannot help regarding the period known as the Renaissance (ranging roughly from the second half of the fourteenth to the first half of the seventeenth centuries) as one of the most fertile and rewarding research fields. It cannot be denied that a particular attention to ways of verbalizing and visualizing thought was fuelled by such historical circumstances at the time as the blossoming of rhetorical studies, a culture saturated with images, and remarkable advances in the technology of knowledge dissemination (one has only to think of the printing press and its impact). This impulse to formulate thought in words and images took a striking variety of forms: the more traditional treatise and the commentary, of course, but also poetry, novel, drama, pageantry, dialogues, emblem books, painting, sculpture and architecture (Giglioni 2016a). It was certainly no accident that Horace's tag ut pictura poesis (Ars poetica, 361: "poetry is like painting") became the motto of an age, and it quickly increased its metaphorizing potential in many directions within the ever expanding field of human ingenuity, so much so that the motto was read quite liberally as ut poesis philosophia and ut pictura philosophia. The most vocal advocate of this liberal use was certainly Giordano Bruno in his works Cantus Circaeus (1582) and De compositione imaginum (1591). ${ }^{3}$

2 Aristotle, Posterior Analytics, I, 13, 78a; Kant 1910-1980, III, pp. 99; IV, pp. 68. On Plato, see Brisson 1998 [1982].

3 Bruno 2004-2009 [1582], I, pp. 668: "Et ideo sicut in scriptura extrinseca atque pictura, quae serviunt oculis extrinsecis, duo requiruntur-ratio videlicet formae atque figurae characterum et imaginum, et materia atque subiectum in quo formae illae et imagines possint subsistere, manere et perdurare-, ita etiam in scriptura intrinseca atque pictura, quae serviunt oculis intrinsecis, duo sunt necessaria;" Bruno, 2004-2009 [1591], II, pp. 660: “Alibi dixi de cognatione quadam mira, quae est inter veros poetas, qui ad eandem speciem referuntur atque musici, veros pictores et veros philosophos; quandoquidem vera philosophia musica seu poesis et pictura est, vera pictura et est musica et philosophia, vera poesis seu musica est divina sophia quaedam et pictura." On early modern interpretation of Horace's ut pictura poesis, see Hagstrum 1958; Lee 
I like to describe this attempt to mediate thinking with textual and visual artefacts as a distinctive trait of Renaissance philosophy. In this development the role of rhetoric was 'gargantuan.' Since antiquity, no doubt, the special nexus of the verbal and the visual in human thinking had been the preserve of the discipline of rhetoric. Enargeia ("vividness," evidentia in Latin) and ekphrasis (verbal description of visual works) are traditionally the most significant illustrations of this mediation (Galand-Hallyn 1995, pp. 99-121; Webb 1999). We also know thatagain since ancient times - the relationship between philosophy and rhetoric has been awkward and difficult, to say the least. And yet, because of the original bond linking words and images together, the return of rhetoric is a recurring episode in the history of western philosophy; we may even say that, at the moment, we are still in the middle of one of such rhetorical turns in philosophy.

Having characterized Renaissance philosophy as a culture of verbal and visual mediation, I have no qualms about recruiting an author like Angelo Poliziano (1454-1594) among its most interesting and representative figures, despite his many attempts at self-effacing and ironic deflection when addressing the question of what philosophy is. As readers of his works, we tend to take Poliziano's cautious self-presentation at face value. Possibly, as a result of his persuasive words, historians of Renaissance culture and philosophy have concentrated their attention on his contributions to methodology (especially in philology and history), intellectual eclecticism, philosophical translation (especially Epictetus) and encyclopedism. ${ }^{4}$ Here I would like to argue that some extra room is left for looking at Poliziano as a philosopher.

For Poliziano, poesis and poetica represented the pinnacle of human endeavours in the field of knowledge. However, it wasn't so much the idea of beauty that he wanted to pursue as the privileged object of poetry, but persuasion, understood as the ability to move oneself and fellow human beings to action by relying on the instruments of reason rather than coercion or deception. In arguing that the sphere of persuasion was broader than the one represented by aesthetic enjoyment, Poliziano's view of

1967; Dolders 1983; Marsh 1989-2013 [1997]; Barkan 2013. More specifically, for Poliziano, see Verde 1973-2010, IV, II, pp. 599-600, who reports a few notes written by Poliziano for a university course on Terence's Andria: "formas imaginesque una spectantes, quasi discere ratiocinarique videmur quicquid sit, ut puta leonem, corvum, hominem."

4 These aspects have been studied by Garin 1954; Maïer 1966; Verde 1973-2010, IV, III, p. 1089; Garin 1994 [1961]; Grafton 1983-1993, I, pp. 9-44; Martelli 1995, pp. 7-71; Mandosio 1996; Kraye 1997; Bausi 2003, pp. XXVII-XXXII; Celenza 2010; Candido 2010; and Robichaud 2010. 
poesis was heavily dependent on the tradition of rhetorical wisdom. Artistic creation did not aim at reaching a state of disinterested contemplation and playful recreation, but strove towards an active transformation of reality through the means of mimetic imagination, make-believe, empathetic recognition and the setting of examples that were worth imitating. We might call this type of rational engagement with reality 'poetic reason,' and Homer, in Poliziano's view, was the perfect embodiment of this kind of reason, both historically and theoretically. As the Iliad and the Odyssey had come to represent the epitome of the Greek ideal of paideia, Homer could be taken to signify the fulfilment of the very idea of humanity. In fact, for Poliziano it wasn't too much of a strain to suggest that behind Homer (the historical record) there was Orpheus (the myth), that is to say, the idea of poetry as the force that turns inanimate beings into sentient agents of cultural progress, endowed with the rhetorical power of persuasion in its purest form (Poliziano 1996, pp. 5-6 [13-16], 191-194 [283-317])..$^{5}$ This resolute statement of poetic reason as a instrument of change and civilization was closely connected — almost interchangeable-with history, the discipline that, in Poliziano's opinion, provided the actual records- the evidence, as it were — of the transformative power of words, symbolical remains and human imagination, but which also set examples to be imitated-better, examples which were willingly imitated because they were desirable.

This is one of the decisive arguments in Poliziano's defence of poetry as the summit of human accomplishments: enduring and memorable testimonies of poetic invention were paradigms that showed the possibility for ever defiant and irrepressible desire - especially in the form of greed and ambition - to respond to the call of reason. History demonstrated that desire could be turned into a force for good every time such drives as imitation, examples, honour, glory, rewards, praise and recognition were convincingly presented as sensible, credible and above all acceptable motives. The ancients used to call this power "decorum;" today we call it decency. In this respect, poetry, history and rhetoric represented for Poliziano the distinctive features of moral imagination.

\footnotetext{
${ }^{5}$ On the different representations of Orpheus's story in Poliziano, from La fabula di Orfeo to the poems Manto and Nutricia, see Bausi, who characterizes the Orpheus in the Fabula as a "fallimentare stagione all'inferno," in evident contrast to the Orphus in the Silvae, where the mythical vates epitomizes the prodigious effects of poetry. See Bausi 2006, pp. 28-34 (30); Bausi 1996, pp. 5-6 and 191-194. See also Garin 1994 [1961], pp. 356-358; Tissoni Benvenuti 1986, pp. 71-88; and Boccuto 1993. On poesis and poetica in Poliziano, see Bettinzoli 1995 and Séris 2002.
} 
Moral imagination has become a staple of contemporary philosophical and aesthetic reflection. Recently, David Bromwich has characterized moral imagination as the "identification of ourselves with something quite radically not our own" (Bromwich, 2014b). ${ }^{6}$ This kind of imagination represents an effort to overcome all those material and conceptual divisions that are interposed among the objects of our experience and that make our perception of reality defective or dogmatically unilateral. The origins of the notion of moral imagination are usually traced back to Edmund Burke (1729-1797), who in his Reflections on the Revolution in France (1790) advocated the necessary preserving function of cultural illusions- "the decent drapery of life". 7 And yet the idea that standards of judgment concern taste as much as moral thinking is also part of the early modern reception of classical ideals of decorum and civility. Moral imagination addresses the question of where we are supposed to draw the line when extolling the representational powers of the imagination and how far we can go in all those situations (fiction, trust, daydreaming, playing) when we are inclined to suspend (for a limited amount of time and remaining vigilant) the critical power of reason.

There is yet another reason why in Poliziano's case to connect knowledge and desire through the paradigmatic function of exemplary actions is essential, and it is a reason that has to do with the function of teaching - a key component in his intellectual development. We know that, starting in 1480, Poliziano was involved in an intensive teaching programme at the Florentine Studium. ${ }^{8}$ A few names and titles will give us an immediate sense of the breadth and diversity of the courses he provided: Quintilian, Ovid, Statius, Rhetorica ad Herennium, Aristotle's Ethics, Physics, Prior Analytics, Virgil's Eclogues and Georgics, and many more. What also

${ }^{6}$ David Bromwich, interviewed by Jonathan Derbyshire, in Prospect Magazine (22 May 2014). See also Bromwich 2014a.

7 Burke 1993 [1790], pp. 77: "All the superadded ideas, furnished from the wardrobe of a moral imagination, which the heart owns, and the understanding ratifies, as necessary to cover the defects of our naked shivering nature, and to raise it to dignity in our own estimation, are to be exploded as a ridiculous, absurd, and antiquated fashion." On various developments in the ever expanding field of studies devoted to moral imagination, see Price 1983, Johnson 1993, Pardales 2002, and Tilmouth 2007.

8 On Poliziano as a teacher, see Verde 1973-2010, IV, I, pp. 381-384, 415-418; II, pp. 491493, 540-544, 595-602, 632-639, 685-694, 768-771, 835-840, 904-910, 945-953; III, pp. 1043-1048, 1087-1092, 1124-1135; Branca 1983, pp. 73-90; Cesarini Martinelli 1996; Bausi 2006, pp. 41-52; Mercuri 2007, pp. XXVII-XLII; and Mandosio 2008. 
emerges from this list is that Poliziano taught philosophy through literature, and not just because he accompanied his lecturing with actual poetic productions (the Silvae were composed as introductions to his university courses) and because he did not hesitate to draw philosophical subjects from literary sources, ${ }^{9}$ but because for Poliziano the very act of thinking could be seen as a craft in which rhetorical and narrative elements converged as one practice of critical understanding. One might therefore say that, in the course of his short but intense career, he demonstrated through the example of his literary output — as a poet, a philologist and a teacher - the meanings of such interrelated activities as thinking, reading and creating. As already mentioned, for Poliziano the unique historical and theoretical embodiment of this vital interdependence was Homer.

\section{HOMER AS THE FATHER OF PHILOSOPHY}

The encounter with Homer was a crucial experience in Poliziano's intellectual career. It marked his entrance into the republic of letters, and it was an entrance that was under the spell of stories, or rather, the story: Homer's Iliad. Indeed, to use a word that has now become dangerously fashionable, his very identity was shaped by that encounter: "ego is sum," is what he proudly announced in his preliminary (and programmatic) lecture on Homer (Oratio in expositione Homeri), given in 1485:

I am the one who, still a boy, burned with such love and passion for this most eminent poet that not only did I smell of Homer after I read the whole of his work and almost wear it out by reading it so many times, but I also dared to translate him into Latin driven by some sort of juvenile and nearly reckless familiarity. ${ }^{10}$

Not surprisingly, Homer is characterized as a vates - that is, a prophet, an oracle and a teacher - the first creator of all sciences and ingenious ideas (doctrinarum

\footnotetext{
9 Poliziano 1970-1971 [1553], I, pp. 229: "Plurima tamen in philosophorum maxime operibus invenias quae sint in poetarum nostrorum libros ascita."

10 Poliziano 1970-1971 [1553], I, pp. 477: "Ego is sum qui ab ineunte adolescentia ita huius eminentissimi poetae studio ardoreque flagraverim, ut non modo eum totum legendo olfecerim peneque contriverim, sed iuvenili quodam ac prope temerario usu vertere etiam in latinum tentaverim." In my translation I have oscillated between "Homer" and "his work" as the object of Poliziano's studium; the original Latin, however, is more direct, for Poliziano refers to Homer the author and Homer the work as one entity defined by the characteristic of personhood (eum).
} 
omnium atque ingeniorum autor et princeps). ${ }^{11}$ "I will demonstrate," Poliziano declares in his lecture, that "never existed a greater mind (ingenium) than the Homeric one, nor a human work that should be placed before Homeric poetry." 12

In his study on Poliziano, Vittore Branca insisted on the important role played by the recently rediscovered Poetics of Aristotle as a catalyst for Poliziano's reflections on art and philosophy (Branca 1983). ${ }^{13} \mathrm{I}$ am more inclined to think that in fact this role should belong to Homer rather than Aristotle-although Aristotle is a key author for Poliziano's ideas on logic, the encyclopedic approach to learning and ethics, and although in a famous letter to Ficino, Poliziano presented himself as the Aristotelian between Marsilio the Platonist and Pico the biblical scholar. ${ }^{14}$ In general terms, though, Poliziano goes back to Homer, and in particular, to Plato's discussion of Homer in the Republic, for, by completely reversing Plato's argument, Poliziano states that in fact poetry is the best philosophy and is the true foundation of political order. ${ }^{15}$

"What shall I say about philosophy?," asks Poliziano in the lecture. His answer makes clear that almost every "noble thought or famous opinion" that we find

11 Poliziano 1970-1971 [1553], I, p. 477: “Dicturus de Homero vate, doctrinarum omnium atque ingeniorum autore et principe, et dicturus in coetu hominum, vel graece, vel latine doctissimorum: sentio nullam eloquentiam nec optari nec concipi posse, quae vel aviditatem animi nostri expleat, vel rei magnitudini respondeat, vel acerrimo denique iudicio vestro atque eruditissimis auribus satisfaciat."

12 Poliziano 1970-1971 [1553], I, p. 478: "planumque (ut arbitror) faciemus, neque ullum unquam extitisse ingenium Homerico maius, neque opus aliquod extare humanum, quod sit Homericae poesi anteferendum."

13 On the diffusion of the Poetica at the time, see Garin 1973.

14 Poliziano 1970-1971 [1553], I, p. 135: “omnes in hoc incumbimus, ut recta studia pro virili iuvemus ac non ullo praemio, sed operis amore solicitati, semper hoc agimus tamen, ita dispensatis inter nos officiis ut nulla ferme studiorum parte cessetur. Etenim Picus ipse Mirandula sacras omnes literas enarrat, adversus ecclesiae septem hostes directa fronte decertat, inter Aristotelem iam meum Platonemque semper tuum caduceator incedit. Tu Platonem, quanquam et alios veteres, sed Platonem tamen ipsum maxime Platonicosque omnes, et latine loqui doces, et uberrimis commentariis locupletas. Mihi vero (quam diu catechumenos in philosophia vestra sum) varietas ista certe literarum cessit, quae non minus habent iucunditatis, etiam si minus autoritatis." On Poliziano and his relationships with Ficino and Giovanni Pico, see Garin 1994 [1961], Gentile 1998, Bettinzoli 2009, and Robichaud 2010.

15 On Poliziano reader of Homer, see Grafton 1992, Galand-Hallyn 1995: 189-210, and Megna 2009. Paola Megna aptly describes Poliziano's praelectio as a "lettura sapienziale di Omero" (Megna 2007, p. LXV). 
among philosophers was already in Homer. ${ }^{16}$ And to corroborate this point, he provides a long sequence of passages, from Thales to the Stoics, whose source can be traced to Homer (Poliziano 1970-1971 [1553], p. 479). Of course, there is a good level of conventional pleasantries and flourishes required by the rhetorical genre against which Poliziano is measuring himself - the encomium. On the other hand, the thesis of poetry as prophecy, and therefore as a foundational element in the construction of human knowledge, was not simply a matter of embellishment, adulation or storytelling. When Poliziano awarded Homer of the title of vates, born in heaven from Calliope herself, the Muse of eloquence and epic poetry (illi et patria coelum insum et mater esse (alliope), it's because he thought that his mastery of language had traced the original coordinates of human learning. And just as "the inspired seers, who in Greek are called prophets, cried out aloud their almost divine responses and oracles, as if from some innermost and holy chambers inhabited by the gods," so Homer was possessed by a divine force, which made him unaware of his earthly condition and divested his work of all references to personal history and gain, completely devoted to the betterment of humankind. ${ }^{17}$ In combining probity, judgment and vision, Homer was the perfect embodiment of moral imagination.

What is especially significant in Poliziano's portrait is the way in which Homer is described as a paragon of virtue, almost of a Stoic kind. Using Silius Italicus's words, Poliziano characterizises Homer's virtue as the self-rewarding effect of noble intent, the sibimet pulcherrima merces. ${ }^{18}$ By doing so, Homer had tamed the two

16 Poliziano 1970-1971 [1553], I, p. 479: “Quid dicam de philosophia, in qua nulla est ferme nobilior posterorum sententia aut opinio celebrata cuius non in poeta Homero originem agnoscamus." ${ }_{17}$ Poliziano 1970-1971 [1553], I, p. 478: "Adeo videlicet sese supra hominis conditionem vates hic eminentissimus atque incomparabilis attollit, adeoque nihil mortale sonat, ut merito illi et patria coelum ipsum et mater esse Calliope videri possit. Atque haec ego de Homeri patria parentibus eo consilio attigi, ut intelligeretis quanta in illo viro altitudo animi rerumque humanarum despicientia qui in tot versuum millibus nullam de patria unquam parentibusque suis fecerit mentionem, imo vero, ne nomen quidem suum aut titulo addiderit aut carminibus inseruerit, sed ut fatidici vates, qui Graeco nomine prophetae appellantur, divina illa sua quasi responsa atque oracula, tanquam ex arcanis quibusdam sacrisque deorum adytis emugiverit, ut plane appareret, non eum sibimet illa, sed omni generi hominum, omnique posteritati elaborasse." ${ }_{18}$ Poliziano 1970-1971 [1553], I, p. 479: "Admirandus profecto vir (quem tamen etiam supra virum crediderim) quem nulla solicitarit ambitio, nulla honoris cupido provexerit, nullum gloriae studium inflammaverit, omnia virtutis causa honestique patraverit, neque sese extra quaesiverit: Ipsa enim est virtus (ut poeta quidam inquit) sibimet pulcherrima merces." See Silius Italicus, Punica, XIII, 663. On the theme of virtue as self-rewarding action, see also Poliziano 1996, p. 141 [417-419]: "Namque licet virtus semet contenta quiescat / sola tamen iustos virtus adsciscit honores, / solaque se merito laudum fulgore coronat.” 
monsters that, in Poliziano's opinion, have never stopped plaguing humankind: greed (avaritia) and ambition (ambitio). ${ }^{19}$ Homer's training in moral integrity occurred through his insatiable desire to know more about reality, while his passion for knowledge drove him to explore innumerable countries and customs throughout his life. ${ }^{20}$ As a result, Poliziano goes on, “in Homer's poetry we contemplate the examples of all virtues and vices, the seeds of all disciplines and the images and effigies of all human things," and-what is more extraordinary, but in fact follows from the creative power of poetry-Homer, who "certainly had never seen these examples with his own eyes," has managed to establish their reality (constituerit) by bringing them forth before our very eyes. ${ }^{21}$ Precisely because of this unique form of ontological constitutio, Poliziano may even say that Homer-the blind poetinvented the art of painting. Echoing a renowned topos attributed to the sixthcentury poet Simonides of Ceos, Poliziano expands on the rhetorical commonplace that poetry deals with talking images while painting is silent poetry. ${ }^{22}$ It's ut pictura poesis all over again, but, beyond all the encomiastic firework, the dictum confirms that, at the root of all visual, poetic and reflexive arguments, it is the imagination and its power to produce images that are capable of setting things in motion-and this is ultimately what artistic creation is all about.

19 Poliziano 1970-1971 [1553], I, p. 479: “Idem et pecuniae possessionem divitiasque pro nihilo habuit, quarum vehementius studium praecepsque cupido divina omnia atque humana permiscuit, ita duas capitaleis humani generis pesteis, duo teterrima monstra, avaritiam atque ambitionem devicit penitus atque prostravit."

20 Poliziano 1970-1971 [1553], I, p. 479: "Quid dicam, quanta quamque inexplebili discendi cupiditate flagraverit, qui ab ineunte adolescentia etiam luminibus captus rerumque omnium egenus, ut qui sibi in diem victum carminibus quaeritaret, etiam peregrinationis incommoda subiit, ut mores hominum multorum multarumque civitatum consuetudines perscrutarent, eaque multiplici rerum peritia, doctior longe indies sapientiorque evaderet."

21 Poliziano 1970-1971 [1553], I, p. 479: "Quo effectum est, ut in Homeri poesi virtutum omnium vitiorumque exempla, omnium semina disciplinarum, omnium rerum humanarum simulacra effigiesque intueamur, ipsaque illa nobis expressa expromptaque ante oculos constituerit, quae ipsemet profecto nunquam suis oculis usurpaverat."

22 Poliziano 1970-1971 [1553], I, p. 489: “Quid si eundem [Homer] picturae quoque magistrum autoremque vocemus, num opinor mentiemur? Cum praesertim sapientis dictum feratur poesin esse loquentem picturam, sicut e contrario pictura ipsa muta poesis vocatur." Poliziano is referring to the dictum by Simonides of Keos: "Poema pictura loquens, pictura poema silens." See Plutarch, De gloria Atheniensium III, 347. See Poliziano 1996, p. 155 [564565], I: "Quin et Apellaeos digitis animare colores / monstrat." 
By turning Homer into a true ontological category, Poliziano can therefore refer to Homeric virtue as a model of both human and divine action. This means that his poetry is not only at the origin of humankind's progress, but it also represents the primordial unity where everything at the beginning existed as one and harmonious, before the split into the many disciplinary and ethical divisions started to afflict the life of the human mind. This point is argued forcefully in one of Poliziano's Silvae, Ambra, where a line says that everything derives from and is in Homer's work. ${ }^{23}$ Like Ocean, the original father of all natural forms, so Homer's voice-the most original and truthful-has fertilized the minds of innumerable generations. ${ }^{24}$ As already mentioned, his words preceded the first utterances of ancient wisdom (sapiens vetustas) and they faithfully reproduce the primeval motions at the origin of the world. Homer-not Hermes, nor Zoroaster-is therefore the priscus theologus (Poliziano 1996, p. 150 [515]).

As we will see in the rest of this article, the thesis of the ontological primacy of poetry through the historical record of Homer - the original undivided union of truth and being - explains why poetry, in Poliziano's opinion, has the power to promote the union of knowledge and action: by recombining the most abstract truths (the self-reflecting intellect) with the drive to moral self-realization (the selfrewarding virtue) through the creation of both inspiring and believable examples (which means by making visible what is inherently invisible), poetry exercises an inherently edifying and civilizing influence in human history. There is a birth in nature that involves all leaving beings, but there is also a cultural birth which is first of all due to poetry, the original nutrix, the wet nurse that, like Orpheus, has turned inanimate matter into animate forces of change and progress.

\section{3. 'THE ANIMAL THAT WE CALL "THE PHILOSOPHER"}

Besides the provision of paradigmatic models and the sense of an original unity of meaning and expression, there is however another key reason why, in Poliziano's opinion, poetry is a fundamentally civilizing force: the function of storytelling. The narrative component in poetry — the mythos - is no ancillary operation, for it represents the very mechanism through which ideas are transformed into examples.

23 Poliziano 1996, p. 147 [481]: “Omnia ab his [Homer's chartae] et in his sunt omnia”; ibid., 580-581: "Omnis ab hoc doctas sapientia fonte papyros / irrigat."

${ }^{24}$ Poliziano 1996, p. 147 [476-480]: "Utque parens rerum fontes et flumina magnae / suggerit Oceanus terrae, sic omnis ab istis / docta per ora virum decurrit gratia chartis; / hinc fusa innumeris felix opulentia saeclis / ditavit mentes tacitoque infloruit aevo." 
As is adroitly and yet forcefully argued in Lamia, the inaugural lecture for his 1492 course on Aristotle's Prior Analytics, fiction is good—and is good for philosophy, too:

We like to chat for a little while, provided that it is to the point (ex re), as Horace says. For little stories (fabellae), even of the kind recounted by grandmothers, are not only a rudiment of philosophy, but sometimes even a philosophical tool. ${ }^{25}$

A story may foreshadow philosophy, but it can also be used to convey philosophical meaning. Moreover, to the inner cogency of arguments, stories add the surprise of accidental events. To stress this point, Poliziano asks for Aristotle's support: "For, as Aristotle says, even philosophers are naturally inclined to stories, that is, they love stories. For a story consists of wonder, and wonder engendered philosophers." ${ }^{26}$ For both Aristotle and Poliziano, wonder is the unexpected revelation following the realization that things are not as we thought they were. In this sense, wonder is the beginning of knowledge and the "mother" of philosophers (Metaphysics I, 982b).

Lamia can be read as an elegant game in which Poliziano muses on whether he is in fact a philosopher by indirectly replying to some Aristotelian colleagues of his - the "witches" of the title-who were questioning his job at the Florentine Studium. Predictably, the first answer he provides is that the witches are right and he is not a philosopher. ${ }^{27}$ As he also remarks in Miscellanea I, he likes to think of his philosophical contribution in terms of a dessert offered at the end of a sumptuous dinner prepared by proper philosophers such as Ficino or Argyropylos. ${ }^{28}$ In the same work, to remain in the sphere of culinary and digestive

25 Poliziano 1970-1971 [1553], I, p. 451; Poliziano 2010, p. 194: "Fabulari paulisper lubet, sed ex re, ut Flaccus ait. Nam fabellae, etiam quae aniles putantur, non rudimentum modo, sed et instrumentum quandoque philosophiae sunt."

26 Poliziano 1970-1971 [1553], I, p. 461; Poliziano, 2010, p. 250: "Siquidem, ut Aristotelis ait, etiam philosophus natura philomythos, id est, fabulae studiosus est. Fabula enim admiratione constat, admiratio philosophos peperit."

27 Poliziano 1970-1971 [1553], I, p. 451; Poliziano, 2010, pp. 198-200: “Videamus ergo primum quodnam hoc sit animal quod homines philosophum vocant, tum spero facile intelligetis non esse me philosophum; neque hoc dico tamen quod id vos credam credere, sed ne quis fortasse aliquando credat; non quia me nominis istius pudeat, si modo ei possim re ipsa satisfacere, sed quod alienis titulis libenter abstineo."

28 Poliziano 1970-1971 [1553], I, p. 217: “Et hercle veluti bellaria sint ista, secundis accepta mensis. Quoniam rectae coenae speciem vicemque graviora illa occupant, qualia tibi multa vel Marsilius Ficinus Platonis, vel Aristotelis interpres Argyropylos Byzantius e philosophiae penu congesserunt." 
metaphors, he describes his role in the philosophical kitchen as that of providing digestive remedies which may aid the metabolism of reading habits and favour the acquisition of acquired tastes:

if sometimes I have sprinkled a few difficult and painstaking — and to be honest, rather sour-points, drawn either from philosophy, to which I have been striving as a candidate for a while now, or from that system of disciplines which attend to the study of wisdom, these bits will perhaps restore and stimulate the stomach of a reader that has become enfeebled by eating over-sweet food. ${ }^{29}$

So, prompted by Poliziano's own game, we should ask with him: What kind of animal is the philosopher (quodnam hoc sit animal quod homines philosophum vocant)? And, more specifically: What kind of philosophical animal is Poliziano? Can philosophers - and Poliziano as a philosopher-be emancipated by the act of fabular? (Where fabulor is not simply the act of having a conversation, but also the ability to tell stories.) To stress the relevance of the narrative side in any exercise of knowledge-and therefore reconfirm the ontological import of poetryPoliziano adds the example of Cicero's way of writing. In the inaugural lecture on Suetonius in the fall of 1490, he characterizes the function of storytelling as the force that injects life and vivid presence into any argument, be that legal or philosophical:

if in Cicero's orations, where everything is said as it should, there are a few short stories that are recounted by going through the whole gamut of emotions and feelings so that matters don't seem to be said, but openly done and set before our eyes, how much more fruitful and abundant everything would appear in the most free field of history, as if this were the Olympic Games? ${ }^{30}$

${ }^{29}$ Poliziano 1970-1971 [1553], I, pp. 214-215: "si paucula respersimus interim scrupulosa et anxia, quodque verius, subacida, vel ex philosophia, cuius iampridem sumus candidati, vel ex orbe illo disciplinarum, quae studio sapientiae famulantur, at ea stomachum tamen lectoris praedulcibus marcentem recreabunt fortassis et exacuent." For the phrase "scrupulosa et anxia," see Aulus Gellius, Noctes Atticae, "Praefatio," 13. On Poliziano and Gellius, see Grafton 2004.

${ }^{30}$ Poliziano 1970-1971 [1553], I, pp. 501: "Nam si in orationibus illis suis, ubi omnia ad praescriptum dicerentur, ita sunt quaedam breves insertae narrationes per omnes ductae sensus atque affectus, ut non dici res illae, sed plane geri atque esse oculis subiectae videantur, quanto uberiora tandem amplioraque omnia in liberrimo illo historiae campo, quasi in Olympiaco curriculo apparuissent" (Praefatio in Svetonii expositionem). The simile between rhetorical performance and running races in Olympia is in Rhetorica ad Herennium IV, 3. 
When Poliziano says that history is the domain of narrative freedom, an activity that is so free that one has the impression to be running at the Olympic Games, he is not taking historia to mean simply a reliable account of past events; he is also not confining his understanding of narratio to the faculty of having conversations about the most disparate topics (fabulari) or sheer fictional invention (condere to the point of falsa narrare simillima veris). The rhetorical question in the quotation above should rather be read as an a fortiori argument: if we tell stories even in contexts where stories are not needed or appropriate, how much more important the act of storytelling will be when the crux of the matter is to recount, that is, history and its liberrimus campus, that area of writing practices where the mind seems to enjoy a condition of almost absolute freedom. Here historia is the technical term that keeps together truth, desire and appearance, for the meaning of historia wavers between account, story and vision; more precisely: between the original act of connecting words to ideas, the fictional tension of make-believe and suspension of disbelief, and imagination as the force that conjures up vivid representations of things-ut pictura poesis. In this sense, history is the domain where things are not simply recounted but done, when ekfrasis and enargeia converge to make visible what otherwise would remains hidden and inarticulate in the depths of the thinking process. Hence history's natural closeness to politics and rhetoric, and, above all, freedom as its distinguishing characteristic. History is the place where reading and writing are a re-enactment of virtue and acting.

It is therefore neither surprising nor far-fetched to argue that for Poliziano history is the essential link between poetry and philosophy. The key argument for him is that there cannot be real philosophy without examples to imitate. Two pithy lines from the poem Ambra captures this point extremely well: "He who is not moved by the idea of a future generation, nor by the reputation that survives him, that is, by examples for other people, loathes his own life and he's a fool."'31 The typical accoutrements of historical narrative and public speaking, such as fama, posteritas and exempla, far from being an expression of vanitas, are all vital values because, in a truly Nietzschean sense, they transform history from a taxidermic venture into a critical exercise in which examples are ways of perpetuating life to future generations. ${ }^{32}$ It is

31 Poliziano 1996, p. 142 [423-424]: "Quem neque posteritas neque tangit fama superstes, / nempe aliis exempla, sibi vitam invidet amens."

32 The reference is, of course, to Nietzsche's On the Uses and Disadvantages of History for Life (Nietzsche 1997 [1874]). On Nietzsche's views on Homer, which have several points in common with Poliziano's, see now Nietzsche 2017. 
also clear that by endorsing a view of virtue as self-rewarding action, Poliziano does not intend to side with an ascetic and analytic view of philosophy, which, rather than capturing the imagination of other people, frightens it with standards of character, conduct and judgment that are way too lofty and forbidding. Instead of being a justification of pure moral intention dissociated from any material result, Poliziano's idea of self-fulfilling rectitude is all about action-epic, heroic, sublime action (all adjectives that, significantly, are literary genres as much as ethical categories)_and it is an idea of virtue that cannot be dissociated from the paradigmatic effects created by feats of glorious action, such as praise, honour, repute and decorum.

And yet traditionally philosophers like to pit virtue against glory. For Poliziano this is the wrong way to assess the profit (merces), the worth (precium) and the award (praemium) of virtue. ${ }^{33}$ Virtuous action needs to be seen together with its glorious consequences: indeed, this is the only way we have to sneak a look at the invisible core of virtue. Otherwise virtue, besides being an invisible experience, turns out to be unreal: "we can see that in these most calamitous times, virtue itself has perished together with its fruit." For Poliziano, there is a certain degree of truth in saying that civilization and its records derive from a desire to be remembered for accomplishing illustrious deeds (cupiditas gloriae). ${ }^{34}$ Poliziano's gloria means reputation, not ambition. He takes the Latin word in his objective_-therefore social_-meaning, signifying the particular stock of beliefs that a community holds about a person or a work. Here glory is no subjective appetite for fame, which elsewhere he calls fastosa, "arrogant" glory. ${ }^{35}$ Indeed, the social function of objective glory is to contain the otherwise untrammelled ambition of subjective glory. What is more, unlike the ephemeral and fruitless productions of individual self-conceit, civilizing and collective glory is better preserved through the many stories recounted about heroic and noble deeds: "What reward for true virtue is more honourable than glory itself, which has built for itself a perpetual abode in the books of the best historians, while it finds temporary accommodation in all kinds of historical records". ${ }^{36}$ In this sense, the

33 Poliziano 1970-1971 [1553], I, p. 499: "Negant sane philosophi quidam appetendam gloriam esse, eamque rectius a virtute velut minime necessariam negligi autumant. Virtus enim, inquiunt, ipsa sibi est precium, ipsa est per sese nullis extrinsecus illecebris expetenda."

34 Poliziano 1970-1971 [1553], I, p. 499: "videre est nostris his calamitosissimis temporibus etiam cum virtutis fructu, virtutem prope ipsam intercidisse."

35 Poliziano 1970-1971 [1553], I, p. 456.

36 Poliziano 1970-1971 [1553], I, pp. 499-500: "Praemium autem quodnam est honestius verae virtutis quam ipsa gloria, quae ut in reliquis monumentis temporarium aliquod habere diversorium potest, ita in excellentium historicorum libris perpetuum sibi domicilium fabricata est?”. 
free field of history, which is the public arena where individuals may exercise the spontaneity of their individual action, is also the place where communal memory is lodged in the form of material and written evidence. So Cicero was right, Poliziano goes on to say in his lecture on Suetonius, when he characterized historical inquiries as a source of intellectual enlightenment (lux veritatis) and a means of driving life into institutions and traditions (vita memoriae). ${ }^{37}$ Through Cicero's all-encompassing meaning of history, as both a theoretical and practical pursuit, Poliziano finds a way of legitimizing the narrative import of philosophy. History provides the philosopher with a field, which is a vast repository of subject matters engaging his mind, and a reasonably broad freedom of movement, which in the end is the changeable expanse of moral imagination-liberrimus ille historiae campus.

What is then the specific contribution of philosophy in this discussion? If rhetoric, poetry and history, with their production of desirable examples, seem to bridge the gap between individuals, communities and universals in relation to both knowledge and action, is there still room for philosophical inquiries in Poliziano's world? We can certainly understand why, given this context, Poliziano preferred to present himself, beyond reasons of studied unpretentiousness, as a grammaticus rather than a philosophus. Not surprisingly, it is especially in Lamia that Poliziano theorizes the role of the grammaticus as an expert in all the disciplines related to the use of language. "These are the functions of grammarians," he declares, "to examine and interpret every kind of writers, poets, historians, orators, philosophers, physicians and lawyers." ${ }^{\text {38 }}$ Unfortunately, he continues, to be a grammarian today is very different from what it used to be:

Our age, barely acquainted with the ideals of antiquity, has confined the grammarian to a role that is too narrow. Among the ancients, by contrast, this profession used to enjoyed such a great authority that grammarians alone were the censors and judges of all writers, and for this reason they were also called critics. ${ }^{39}$

\footnotetext{
37 Poliziano 1970-1971 [1553], I, pp. 499-500. See Cicero, De oratore, II, 36.

38 Poliziano 1970-1971 [1553], I, pp. 461; Poliziano 2010, p. 244: “Grammaticorum enim sunt hae partes, ut omne scriptorum genus poetas, historicos, oratores, philosophos, medicos, iureconsultos excutiant atque enarrent."

39 Poliziano 1970-1971 [1553], I, p. 461; Poliziano 2010, p. 244: "Nostra aetas parum perita rerum veterum, nimis brevi gyro grammaticum sepsit; at apud antiquos olim tantum autoritatis hic ordo habuit, ut censores essent et iudices scriptorum omnium soli grammatici, quos ob id etiam Criticos vocabant."
} 
As a grammaticus, Poliziano sees himself as fully equipped with all the instruments supplied by philology, history and poetics so as to be able to embark on a critical survey of reality. Moreover, as a critic, and not as a professional philosopher, he can remain loyal to his view of poetry as the best instantiation of philosophical inquiry, without losing track of the countless historical accidents and accretionsall perfectly meaningful — that derive from the use of any language. And yet things are not so simple, for, besides being an elegant exercise in philosophical selfeffacement, Lamia remains a paean to philosophy. I would say that it has to be such a paean, for any defence of poetry as philosophy risks to advocate (even unwittingly) the right to be deluded and to act in a delusional way, that is, to inadvertently promoting escapism and analgesic fantasy. The element of critical thinking in Poliziano's definition of grammaticus needs therefore to be unpacked. The philosopher as a critic alerts his readers to the dangers of acquiescence and reminds them of the parlous state of things in the real world.

As a result, philosophy is for Poliziano the discipline that "presses her favours on those who are awake, not asleep" (Vigilantibus enim se, non dormientibus ingerit):

in order for you to understand more easily what I said — that the greatest pleasure lies in philosophy-picture in your minds someone who has all the pleasures of this world, who knows nothing and lacks all judgment: is there anyone who would like to live the life of this person? I don't think so, just as no one would choose to always be drunk, always be a child and always be asleep, like Endymion. For, although there are indeed some joys in sleeping, those joys, however, are false, counterfeited, imaginary, not true, not solid and not clear. And why do you think we are all frightened by death? It's because everyone finds what they don't know dreadful, as something that is obscure and shrouded in darkness, just as, on the contrary, they love what they understand, as something that is clear and distinct. ${ }^{40}$

40 Poliziano 1970-1971 [1553], I, pp. 456; Poliziano 2010, pp. 224-226: “Sed quod voluptatem diximus esse in philosophia maximam quo facilius intelligere possitis, fingite aliquem vobis cunctis affluentem deliciis, qui nihil omnino sapiat, qui prudentia penitus vacet, an quisquam vivere huius vitam volet? Equidem non puto: sicuti nec semper ebrius, nec semper esse puer, nec dormire semper, ad morem Endymionis, eligat quispiam. Quanquam enim aliqua etiam in somnis gaudia sunt, falsa illa tamen, adumbrata, imaginaria, non vera, non solida, non expressa sunt gaudia. Cur autem et mortem prope omnes expavescimus? Quoniam puto cuique terribile quod ignoratur, ut quod obscurum, quod tenebricosum est: sicuti contra amabile quod intelligitur, ut quod apertum, quod illustre est." On the interplay of dreaming and waking in Renaissance philosophy and medicine, see Giglioni 2016b. 
Endymion, with his story of deathless and ageless sleep, represents for Poliziano a state of mental torpor, which may be good for the indefinite preservation of the vegetative functions of life, but it has no part in strengthening the fibre of moral reasoning. On the contrary, numbness is bound up with that sense of discomfort that humans associate with death. Only a condition of awareness predicated on knowledge of reality (historia) ensures that the human mind has a clear perception of the state of things in the real world:

if we love what we know, why do we also love the very actions of knowing and possessing knowledge? But this is precisely what defines philosophy more than anything else. So either we shouldn't do and wish anything in this life, or we should put all our hopes in philosophy, our haven. Let us place the life of human beings before our eyes: what is that life apart from a vain shadow, or, to use Pindar's apter words, the dream of a shadow? Man is a bubble, says an old proverb. Consider the elephant and the little hare, how stronger the one and faster the other are compared to us. What is this haughty glory (gloria fastosa) that most of the times drives us headlong if not mere nonsense and hot air? If you look at that from afar, you may think that it's something great; when you come closer, it fizzles out. ${ }^{41}$

There are degrees in the human ability to perceive reality behind the screen of appearances, and there are also different ways of protecting that ability from sudden and disruptive clashes with reality. An excessively keen sight may jeopardize the precarious balance that exists between the mind and its surrounding reality: "if we were sharp-sighted like Lynceus, and we could see through bodies and look inside them, we would look at even the most beautiful people with revulsion, so many are the things that would appear to us hideous, loathsome and disgusting." To prevent that an excess in clear-sightedness may turn knowledge into a purely destructive exercise, minds necessitate the buffer of beliefs and imaginations that shield them from the shock of raw, unprocessed reality:

41 Poliziano 1970-1971 [1553], I, p. 456; Poliziano 2010, p. 226: “Si igitur quae nota sunt delectant, cur etiam nosse ipsum ac sapere delectet? At id maxime proprium philosophiae est; aut igitur nihil agendum in hac vita, nihil expetendum est, aut in sola philosophia, tanquam in portu requiescendum. Subiiciamus quaeso oculis hominum vitam. Quid ea est omnis praeter inanem umbram, vel, ut significantius ait Pindarus, umbrae somnium? Homo bulla est, antiquum inquit proverbium. Nam quantum viribus ab elephanto, quantum celeritate vincimur a lepusculo? Gloria haec autem fastosa, quae nos plerunque agit praecipites, ut nihil aliud est quam merae nugae? Ut nihil aliud quam nebula? Procul enim si spectes, magnum quiddam esse putes; ubi propinques, evanescit." 
In conclusion, what is solid and long lasting in all our things? The weakness of our nature and the brevity of our life lead us to think that sometimes something may stand firm or last. This may explain why the belief of some of the ancientsthat our souls, by having being thrown into our bodies as in a jail, were paying the penalty of serious crimes-although not entirely true, cannot nevertheless be dismissed as completely absurd. For, since the soul is united and glued to the body, extended and unfolded throughout the limbs and the passageways of the senses, this soul seems to me to suffer a torment that is no different from the one to which the abominable Mezentius in Virgil subjected his unfortunate citizens. ${ }^{42}$

Philosophy is the discipline that mediates between Endymion and Lynceus, between illusion and disillusion, sleep and rude awakening. A philosopher cannot torture the human mind, as Mezentius - the heinous and irreligious Etruscan king-used to do with his enemies, when he would tie their bodies to festering corpses_- "face to face," as recounted by Vergil in the Aeneid (VIII, 483-488). Poliziano does not deny that philosophers are contented with "the contemplation of the loftiest things (pulcherrima)." 43 They are "devoted" to the knowledge of what is "high, divine and pure," understood in its very source (in fonte), and this knowledge is called sophia in Greek and sapientia in Latin. ${ }^{44}$ Poliziano is also aware, however, that in mediating between Endymion and Lynceus, philosophers have the responsibility to account for the value and meaning of beliefs that shape human communities and prevent them from falling apart. It is highly likely that,

42 Poliziano 1970-1971 [1553], I, pp. 456-457; Poliziano 2010, pp. 226-227: "Nam si lyncei essemus, ac penetrare oculis in corpora et introspicere possemus, etiam formosissimum quemque nauseabundi aspiceremus, adeo nobis multa visu tetra et foeda prorsusque deformia occurrerent. Quid obscoenas commemorem voluptates, quibus poenitentia semper comes. Age vero, quid in rebus nostris omnibus vel solidum vel diuturnum? Nam ut stare aliquid aut durare nonnunquam putemus imbecillitas nostra facit atque aevi brevitas, ita quod veteres opinati quidam sunt animas nostras in corpora tanquam in carcere coniectas magnorum scelerum poenas luere, quanquan non omnino verum, tamen etiam nec absurdum plane videri potest. Nam cum sit anima iuncta agglutinataque corpori, ac per omneis artus, omneisque sensuum quasi meatus extenta et explicata, non alio mihi videtur supplicio affecta quam quo Mezentius ille Vergilianus miseros cives suos afficiebat."

43 Poliziano 1970-1971 [1553], I, p. 452; Poliziano 2010, pp. 204-206: “Sed inter omneis praecellere tamen eos, et esse quam honestissimos, qui rerum pulcherrimarum speculatione contenti sunt."

44 Poliziano 1970-1971 [1553], I, p. 453; Poliziano 2010, p. 206: “Quotcunque igitur pulchra, divina, sinceraque primo, hoc est, in fonte ipso sunt, eundemque tenorem peragentia, horum esse scientiam quandam, quae sophia nominatur, id nomen latine sapientia est, eiusque sophiae studiosum vocatum modo esse a se philosophum.” 
similarly to the victims of Mezentius, in many of our daily actions we live in the embrace of death, for reality is a rather nauseous affair. Luckily, though, our eyes are not as sharp as those of Lynceus, and instead of attempting to disembody our perception through intellectual abstraction or falling in a dreamless sleep, our condition of temporal agents invites us to resort to stories, provided that they have a relevant point (ex re) and are related to the life of a historical community.

\section{CONCLUSION: TO REASON, TO RATIONALIZE-PERCHANCE TO DREAM}

It is at this extremely delicate juncture-between persuasion (fides), recognition (verum) and innner transformation (exemplum) — that philosophy and poetry seem to reach a precarious and yet firm agreement. In the lecture on Suetonius, Poliziano explains that those who are regarded as the greatest poets were able to convince their audience of any thing they liked. But in order to do so, as Cicero explained and did in his career as an orator, they also needed to be 'historians', that is, people capable of handling reality and the impact that reality had on their imagination and that of their hearers. What is more, as the Muses once reminded Hesiod, poets, insofar as they are chroniclers of reality, know how to distinguish the truth from the falsity of things (Scimus falsa quidem narrare simillima veris: / Scimus item, quoties libitum est, et vera profari). And to end this progression with a climax, Poliziano introduces the figure of the legumlator, the mind who creates the laws of a country. Here, at the level of political inventio, is where the productive significance of poetry, history and philosophy is at its highest (Poliziano 1970-1971 [1553], p. 501).

Fides (belief and trust) and facere fidem (to persuade) are the technical terms used by Poliziano in this discussion. Belief and trust are what turns the virtue as selfrewarding endeavour into a promise of history and civilization. And while gloria (honour and praise) can be a noble motive behind the accomplishment of virtuous actions, history has the advantage over both poetry and philosophy that it produces belief (facere fidem) and garners consent among people. In this, history is more persuasive than any poetic or philosophical representations of reality, which in fact must rely on the examples of history if they want to be believable (Poliziano 19701971 [1553], pp. 501-502). Not only that; they need history if they want to keep desire away from the opposite threats of dull habituation and unhinged appetite. As said at the beginning of this article, in Poliziano's analysis of the motives behind human action, examples sublimate the murky underside of greed and ambition into a desire for insight and change. Significantly, Poliziano never demonizes cupiditas gloriae, the desire of glory, every time glory means laudable and exemplary action. 
Indeed, he does not demonize either cupiditas or gloria whenever they are understood as a force of vital growth and a source of civilizing effects. In this sense, it is correct to say that Poliziano learnt his philosophy at the school of Homer.

If we now go back to the beginning of Lamia, the meanings of fabella and res become clearer. Philosophers like to tell stories, but their stories have to be "to the point," ex re, "as Horace says." Here the meaning of res is the matter under discussion rather than adaptation to external circumstances; it's materia more than occasio. Let's have a quick look at what Horace said in Satira, II, 6, which is the place referred to by Poliziano. This is Horace's example of telling stories ex re:

And so we start to talk, not about other people's villas or houses, or whether Lepos dances well or not, but - and this is what really matters to us and is something that one should know-whether human beings are happy because of their money or their virtue, what brings us friends, whether interest or honesty, and what the nature of the good and the highest good are. While discussing these matters, my neighbour Cervius chatters away and recounts those bedtime stories that are commonly told by grandmothers, but he does so while sticking to the point (ex re). ${ }^{45}$

Cervius's stories are aniles fabellae, and yet they are apposite developments of the conversation (fabular), for they illustrate the matter (res) of the sermo, that is, the meaning of happiness, virtue, friendship; above all, they shed light on the nature of the good. In this way, these stories manage to reconcile desire (cupiditas) with reality (res). Through Cervius, Horace retells Aesop's story of the town mouse and the country mouse, which at the end of the poem reconfirms the ideals of frugality and restraint advocated by the poet at the beginning of his satira (boc erat in votis... nibil amplius oro, 1,4$).^{46}$

One might say that, as is the case with Poliziano, Horace's relationship to philosophy was too elusive to be taken as evidence of any real commitment. For some commentators, Horace's interest in Stoic and Epicurean thought was a matter of poetic occasion more than a consistent intellectual pursuit, just as Poliziano's involvement with the philosophy of the ancients was a response to professional

${ }^{45}$ Horace, Satires, II, 6, 70-78: “ergo / sermo oritur, non de villis domibusve alienis, / nec male necne Lepos saltet; / sed, quod magis ad nos / pertinet et nescire malum est, agitamus, utrumne / divitiis homines an sint virtute beati, / quidve ad amicitias, usus rectumne, trahat nos / et quae sit natura boni summumque quid eius. / Cervius haec inter vicinus garrit aniles / ex re fabellas." 46 As a further example of recounting stories according to the res of the situation and the time, see Cowley's retelling of the Horatian fable of the two mice. Cf. Hopkins 1993, pp. 103-125. 
and didactic demands. ${ }^{47}$ This, however, is a reading that has the inconvenience of distorting the meaning of Poliziano's philosophical concerns. Res—reality more than circumstance-is what for him connects story to history and makes the storytelling significant even from a philosophical point of view. Likewise, the philosopher is that particular animal that reminds all storytellers - including the philosophical storytellersto "vigilate" and keep their eyes wide open, not to fall in Endymion's sleep, but also to avoid any direct and unmediated engagement with reality, a violent attitude symbolized by Mezentius's torture and by Lynceus's immodest and unvirtuous gaze. Between the extremes of numbness and violation, Poliziano validates the philosophical dream of reason, as a kind of investigation in which the critical powers of the grammaticus are not suspended but enhanced through the use of irony and imagination. And here it may be worth pointing out, in passing, that this philosophical consideration of fiction has nothing to do with the political uses of stories and myths that was being advocated at the time by some representatives of Renaissance Aristotelianism as a means of controlling the unruly behaviour of the masses.

We tend to think of philologists as priests and vestals of the written word, grim and stern in their efforts to enact the laws of literary decorum. When I think of Poliziano, my mind immediately goes to the "free" fields of knowledge and playfulness. If we look at the process of thinking as a craft designed to train the imagination and memory of human beings so that they become able to express and communicate what otherwise would be left dormant in the domain of conceptual inarticulacy (with not a few risks attached), then the practice of reading takes on a crucial role. There cannot be proper thinking without proper reading. This is one of the many provisos expressed by Poliziano in his Miscellanea of 1489. The diversity of natural and human experience (varietas and disparilitas) is the catalyst (expultrix and irritatrix) that activates reading, understood as both a remedy against the dulling of desire (fastidium) and a booster to hone perceptual discernment. This diversity is also the reason why silvae and farragines, far from setting the mind adrift, are modes of inquiry that keep our mental faculties alert, ready to identify similarities and differences. ${ }^{48}$ An integral part of the craft of

47 For a few views concerning the philosophical attitude of Horace, see Schrijvers 1993, Rudd 1993, Moles 2002, and Mayer 2005.

48 Poliziano 1970-1971 [1553], I, p. 213: "si varietas ipsa, fastidii expultrix et lectionis irritatrix, in Miscellaneis culpabitur, una opera reprehendi rerum quoque natura poterit, cuius me quidem profiteor tali disparilitate discipulum" (Miscellaneorum centuria prima, "Praefatio"). A similar strategy can be seen in the way in which Bacon characterizes the practices of reading and writing. See Giglioni 2014. 
thinking lies in taking good care of the imagination and in shaping it into a force of moral agency. As indicated by Poliziano in his analysis of exempla, gloria and the campus of history, moral imagination depends on striking the right balance between virtue and spontaneity: "Often an excess in precision is counterproductive. And just as a dress that is appropriate and elegant adds to the authority of its wearer, so one that is garish and over the top stains the good of virtue with meretricious allurement." ${ }^{\prime 9}$ Moral vision rests on a subtle interplay of desire (cupiditas), action (virtus) and representational energy (imagines).

It is therefore moral imagination that warrants the philosophical import of fiction. Causes and laws, quiddities and reasons of principle may have the unique privilege of dwelling in the immutable space of an eternal present. The prose of facts and quoddities, however, is subject to the passing of time and therefore requires stories about our imagined past and our imagined future in order for us to make sense of those very causes and laws that we hold so dear. As noted above, Poliziano shares with Aristotle the view that the sense of wonder announces the unexpected and liberating promise that things are not the way we thought they were. Being linked to wonder, stories are the accidents that periodically subvert our perception of an inexorable series of causes and effects in nature. Stories themselves, owing to their pliable and yielding nature, are exposed to the possibility of being interrupted, as intimated by the proverbial wolf, which makes us unable to articulate words when we suddenly discover that it has been staring at us (lupus in fabula $).{ }^{50}$ And yet philosophers, as both Horace and Poliziano encourage us to think, are always there to find a way to recover the lost words and resume the interrupted conversation (be that a sermo or a fabula), and they do this by welding the poetry of the law with the prose of the facts.

\section{Guido Giglioni \\ Università di Macerata guidomaria.giglioni@unimc.it}

\footnotetext{
49 Poliziano 1970-1971 [1553]: 494: "Nocet enim profecto saepe nimia diligentia. Et ut cultus concessus atque magnificus addit autoritatem, ita accersitus ille atque fucatus bonam ipsam virtutem lenocinio contaminat" (Oratio super Fabio Quintiliano et Statii Sylvis). See Quintilian, Institutio oratoria VIII, 20.

${ }^{50}$ On the various meanings of the proverb lupus in fabula, see Erasmus, Adagia, IV, V, 50.
} 


\section{BIBLIOGRAPHY}

Barkan, L. (2013): Mute Poetry, Speaking Pictures, Princeton: Princeton University Press. BAusi, F. (1996): "Introduzione," in A. Poliziano, Silvae, ed. F. Bausi, Florence: Olschki, pp. XI-XXXI.

— (2003): "Introduzione," Due poemetti latini: Elegia a Bartolomeo Fonzio; Epicedio di Albiera degli Albizi, ed. F. Bausi, Rome: Salerno, pp. XI-XLVIII.

— (2006): “Introduzione," pp. 7-52.

BetTinzoli, A. (1995): Daedaleum iter: Studi sulla poesia e la poetica di Angelo Poliziano, Florence: Olschki.

- (2009): La lucerna di Cleante: Poliziano tra Ficino e Pico, Florence: Olschki.

Boccuto, G. (1993): "Il mito di Orfeo nei Nutricia di Poliziano," in L. Rotondi Secchi Tarugi (ed.), Il mito nel Rinascimento, Milan: Nuovi Orizzonti, pp. 217-240.

BRANCA, V. (1983): Poliziano e l'umanesimo della parola, Turin: Einaudi.

BRisson, L. (1998 [1982]): Plato the Myth Maker, ed. G. Naddaf, Chicago: The University of Chicago Press.

Bromwich, D. (2014a): Moral Imagination: Essays, Princeton: Princeton University Press.

— (2014b): interview, Prospect Magazine (22 May 2014) URL = http://www.prospectmagazine. co.uk/blogs/jonathan-derbyshire/temptations-of-empire-a-conversation-withdavid-bromwich. [1-8-2017]

Bruno, G. (2004-2009 [1582]): Cantus Circaeus, in Opere mnemotecniche, ed. M. Matteoli, R. Sturlese and N. Tirinnanzi, Milan: Adelphi, vol. I, pp. 586-806.

BRunO, G. (2004-2009 [1591]): De compositione imaginum, in Opere mnemotecniche, ed. M. Matteoli, R. Sturlese and N. Tirinnanzi, Milan: Adelphi, vol. II, pp. 482-978.

BurKe, E. (1993 [1790]): Reflections on the Revolution in France, ed. L. G. Mitchell, Oxford: Oxford University Press.

CANDidO, I. (2010): “The Role of the Philosopher in Late Quattrocento Florence: Poliziano's Lamia and the Legacy of the Pico-Barbaro Epistolary Controversy," in Angelo Poliziano's Lamia: Text, Translation, and Introductory Studies, ed. C.S. Celenza, Leiden: Brill, pp. 95-129.

Celenza, C.S. (2010): "Poliziano’s Lamia in Context," in Angelo Poliziano's Lamia: Text, Translation, and Introductory Studies, ed. C.S. Celenza, Leiden: Brill, pp. 1-46.

Cesarini MartinelLi, L. (1996): "Poliziano professore allo studio fiorentino," in R. Fubini (ed.), La Toscana al tempo di Lorenzo il Magnifico, 3 vols., Pisa: Pacini, II, pp. 463-481.

Dolders, A. (1983): “'Ut Pictura Poesis': A Selective Annotated Bibliography of Books and Articles, Published between 1900 and 1980 on the Interrelation of Literature and Painting between 1400 and 1800," Yearbook of Comparative and General Literature, v. 32, pp. $105-124$.

Galand-Hallyn, P. (1995): Les yeux de l'éloquence: Poétiques bumanistes de l'évidence, Orléans: Paradigme. 
GARIN, E. (1954): "Filologia e poesia in Poliziano," La Rassegna della Letteratura Italiana, v. 58, pp. 349-366.

- (1973): "La diffusione della Poetica di Aristotele dal sec. XV in poi," Rivista Critica di Storia della Filosofia, v. 28, 447-469.

- (1994 [1961]): "L'ambiente del Poliziano," in La cultura filosofica del Rinascimento italiano: Ricerche e documenti, Milan: Bompiani, pp. 335-358.

Gentile, S. (1998): "Poliziano, Ficino, Andronico Callisto e la traduzione del Carmide platonico," in V. Fera and M. Martelli (eds.), Agnolo Poliziano, poeta, scrittore, filologo, Florence: Le Lettere, pp. 365-385.

Giglioni, G. (2014): "From the Woods of Experience to the Open Fields of Metaphysics: Bacon's Notion of Silva," Renaissance Studies, v. 28, pp. 242-261.

- (2016a): "What's Wrong with Doing History of Renaissance Philosophy? Rudolph Goclenius and the Canon of Early Modern Philosophy," in C. Muratori and G. Paganini (eds.), Early Modern Philosophy and the Renaissance Legacy, Dordrecht: Springer, pp. 21-39.

- (2016b): "Delusion, Drowsiness and Discernment: Degrees of Awareness in Renaissance Dream Activity," in I. Mac Carthy, K. Sellevold and O. Smith (eds.), Cognitive Confusions: Dreams, Delusions and Illusions in Early Modern Culture, Cambridge: Legenda, pp. 89-109.

GODMAN, P. (1993): “Poliziano’s Poetics and Literary History,” Interpres, v. 13, pp. 110-209. Grafton, A. (1983-1993): Joseph Scaliger: A Study in the History of Classical Scholarship, Oxford: Clarendon Press. 2 vols.

- (1991 [1977]): "On the Scholarship of Politian and Its Context," in Defenders of the Text: The Traditions of Scholarship in an Age of Science, 1450-1800, Cambridge, MA: Harvard University Press, pp. 47-75 [originally published in the Journal of the Warburg and Courtauld Institutes, v. 40 (1977), pp. 150-188].

- (1992): "Renaissance Readers of Homer's Ancient Readers," in R. Lamberton and J.J. Keaney (eds.), Homer's Ancient Readers: The Hermeneutics of Greek Epic's Earliest Exegetes, Princeton: Princeton University Press, pp. 149-172.

- (2004): "Conflict and Harmony in the Collegium Gellianum," in L. Holford-Strevens and A. Vardi (eds.), The Worlds of Aulus Gellius, Oxford: Oxford University Press, pp. 318-342.

Hagstrum, J. H. (1958): The Sister Arts: The Tradition of Literary Pictorialism and English Poetry from Dryden to Gray, Chicago: University of Chicago Press.

Hopkins, D. (1993): “Cowley's Horatian Mice," in C. Martindale and D. Hopkins (eds.), Horace Made New: Horatian Influences on British Writing from the Renaissance to the Twentieth Century, Cambridge: Cambridge University Press, pp. 103-125.

Johnson, M. (1993): Moral Imagination: Implications of Cognitive Science for Ethics, Chicago: The University of Chicago Press.

KANT, I. (1910-1980): Gesammelte Schriften, ed. Königlich Preussischen Akademie der Wissenschaften, Berlin and Leipzig: Reimer and De Gruyter. 29 vols. to date. 
Kraye, J. (1997): “Angelo Poliziano,” in J. Kraye (ed.), Cambridge Translations of Renaissance

Philosophical Texts, Cambridge: Cambridge University Press, I, pp. 192-199.

LEE, R. W. (1967): Ut Pictura Poesis: The Humanistic Theory of Painting, New York, Norton. MAÏER, I. (1966): Ange Politien: La formation d'un poète humaniste (1469-1480), Geneva: Droz. Mandosio, J.-M. (1996): "Filosofia, arti e scienze: L'enciclopedismo di Angelo Poliziano," in L. Secchi Tarugi (ed.), Poliziano nel suo tempo, Florence: Cesati, pp. 135-164.

- (2008): 'Un enseignement novateur: Les cours d'Ange Politien à l'université de Florence (1480-1494)," Histoire de l'Éducation, 120, pp. 33-54.

Marsh, D. (1989-2013 [1997]): “Ut pictura poesis," in H.B. Nisbet and C. Rawson (eds.), The Cambridge History of Literary Criticism. IV. The Eighteenth Century, Cambridge: Cambridge University Press, pp. 681-699.

Martelli, M. (1995): Angelo Poliziano: Storia e metastoria, Lecce: Conte.

MAYER, R. (2005): "Sleeping with the Enemy: Satire and Philosophy," in K. Freudenburg (ed.), Cambridge Companion to Roman Satire, Cambridge: Cambridge University Press, pp. 146-159.

MegnA, P. (2007): "Introduzione," in Oratio in expositione Homeri, ed. P. Megna, Rome: Edizioni di Storia e Letteratura, pp. XXI-XC.

- (2009): Le note di Poliziano alla traduzione dell'Iliade, Messina: Centro Interdipartimentale di Studi Umanistici.

MERCuRI, S. (2007): “Introduzione,” in A. Poliziano, Latini, ed. S. Mercuri, Rome: Edizioni di Storia e Letteratura, pp. XVII-LXXI.

Moles, J. (2002): "Poetry, Philosophy, Politics, and Play, Epistles I," in A.J. Woodman and D.C. Feeney (eds.), Traditions and Contexts in the Poetry of Horace, Cambridge: Cambridge University Press, pp. 141-157.

NiETzSCHE, F. (1997 [1874]): On the Uses and Disadvantages of History for Life, in Untimely Meditations, ed. D. Breazeale, trans. R. J. Hollingdale, Cambridge: Cambridge University Press, pp. 57-123.

- (2017): Le cas Homère, ed. C. Santini, Paris: Éditions de l'École des Hautes Études en Sciences Sociales.

Pardales, M. J. (2002): “'So, How Did You Arrive at That Decision?’ Connecting Moral Imagination and Moral Judgement," Journal of Moral Education, v. 31, pp. 423-437.

POLIZIANO, A. (1970-1971 [1553]): Opera quae quidem exititere hactenus omnia longe emendatius quam usquam antehac expressa, Basel: Nicolaus Episcopius the Younger; reprint ed. I.

Maïer, Turin: Bottega d'Erasmo. 3 vols.

- (1986): Lamia: Praelectio in Priora Aristotelis analytica, ed. A. Wesseling, Leiden: Brill.

- (1996): Silvae, ed. F. Bausi, Florence: Olschki.

- (2003): Due poemetti latini: Elegia a Bartolomeo Fonzio; Epicedio di Albiera degli Albizi, ed. F.

Bausi, Rome: Salerno.

— (2006): Poesie, ed. F. Bausi, Turin: UTET.

- (2007a): Latini, ed. S. Mercuri, Rome: Edizioni di Storia e Letteratura.

- (2007b): Oratio in expositione Homeri, ed. P. Megna, Rome: Edizioni di Storia e Letteratura. 
Poliziano, A. (2010): Lamia, in Angelo Poliziano's Lamia: Text, Translation, and Introductory Studies, ed. C. Celenza, Leiden: Brill, pp. 191-254.

PRICE, M. (1983): Forms of Life: Character and Moral Imagination in the Novel, New Haven: Yale University Press.

Robichaud, D. J.-J. (2010): “Angelo Poliziano's Lamia: Neoplatonic Commentaries and the Plotinian Dichotomy between the Philologist and the Philosopher," in Angelo Poliziano's Lamia: Text, Translation, and Introductory Studies, ed. C. Celenza, Leiden: Brill, pp. 131-190.

RudD, N. (1993): “Horace as a Moralist," in N. Rudd (ed.), Horace 2000: A Celebration, Ann Arbor: University of Michigan Press, pp. 64-88.

SCHRIJVERS, P. H. (1993): "Horace moraliste," in W. Ludwig (ed.), Horace: L'oeuvre et les imitations, un siècle d'interprétation, Vandoeuvres and Geneva: Fondation Hardt, pp. 41-94.

SÉRIS, É. (2002): Les étoiles de Némésis: La rhétorique de la mémoire dans la poésie d'Ange Politien (1454-1494), Geneva: Droz.

Tilmouth, C. (2007): Passion's Triumph over Reason: A History of the Moral Imagination from Spenser to Rochester, Oxford: Oxford University Press.

Tissoni Benvenuti, A. (1986): L'Orfeo del Poliziano: Con il testo critico dell'originale e delle successive forme teatrali, Padua: Antenore.

VERDE, A.F. (1973-2010): Lo Studio fiorentino 1473-1503: Ricerche e documenti, Florence: Istituto Nazionale di Studi sul Rinascimento and Olschki. 6 vols.

WEBB, R. (1999): “Ekphrasis Ancient and Modern: The Invention of a Genre," Word and Image, v. 15, pp. 7-18.

Wesseling, A. (1986): "Introduction," in Lamia: Praelectio in Priora Aristotelis analytica, ed. A. Wesseling, Leiden: Brill, pp. XII-XXXVIII. 